\title{
Metro Hatlarının Konut Fiyatlarına Etkisine İlișkin Literatür Taraması
}

\author{
Literature Survey Regarding with the Affects of Metro Lines On House Prices
}

\author{
(D) Kamil DEMIRCAN, ${ }^{1}$ 이 Senay OĞUZTIMUR²
}

ÖZ

Metro hatları, kentçi raylı sistemlerin en önemli parçasını oluşturmaktadır. Bu çerçevede ortaya çıkardığı sosyoekonomik etkiler gün geçtikçe daha fazla merak konusu olmaktadır. Genel olarak metro hatlarının konut fiyatlarını artıran yönde etkiler yarattığına yönelik çalışmalara sıklıkla rastlanmaktadır. Bununla birlikte konuya farklı bakış açıları ile yaklaşan çalışmalar ve sonuçlar da bulunmaktadır. Bu makale kapsamında, literatürde metro hatlarının konut fiyatlarını etkilemesi çerçevesinde yapılan çalışmalar yöntem ve bulguları açısından ele alınmış, dünyanın farklı coğrafyalarında bu konuya nasıl yaklaşıldığı ile ilgili görüşler ortaya konulmuştur. Bu kapsamda çalışmanın amacı, metro hatlarının konut fiyatlarını ne şekilde etkilediğine yönelik yapılan akademik araştırmalardaki farklı bakış açılarını bir özet niteliğinde ortaya koymaktır. İncelenen literatüre göre metro hatları, erişebilirlik düzeyini artırması sebebiyle ve ortaya çıkardığı pozitif dışsallıklar nedeniyle genel olarak konut fiyatlarını artıran etkiler yaratmaktadır.

Anahtar sözcükler: Değer artışı; hedonik fiyat yöntemi; konut fiyat;; metro hatları; raylı sistem hatları.

\section{ABSTRACT}

Metro lines are the most important part of urban rail systems. The socio-economic effects in this frame become an area of interest day by day, whereas studies regarding the effect of metro lines on increase of real estate prices prevail. However, there are also other studies and evaluations with different approaches. In this article, the studies regarding the effect of metro lines on real estate prices will be evaluated in terms of methods and findings, and various views around the world about these issues will be put forward. In this context, the purpose of this study is to summarize the different perspectives in the academic researches on how the metro lines affect the housing prices. According to the literature reviewed, metro lines have generally increased housing prices due to the increase in accessibility and positive externalities.

Keywords: Land price; hedonic price modelling; value capture; metro lines; railway lines.

'Yıldız Teknik Üniversitesi Şehir ve Bölge Planlama Doktora Programı Öğrencisi, İstanbul

${ }^{2}$ Yıldız Teknik Üniversitesi Mimarlık Fakültesi, Şehir ve Bölge Planlama Bölümü, İstanbul

Başvuru tarihi: 12 Mart 2019 - Kabul tarihi: 17 Ağustos 2019

İletişim: Senay OĞUZTiMUR. e-posta: soguz@yildiz.edu.tr

○ 2019 Yıldız Teknik Üniversitesi Mimarlık Fakültesi - @ 2019 Yıldız Technical University, Faculty of Architecture 


\section{Giriş}

Metro projeleri hı, konfor, güvenlik, güvenilirlik gibi parametrelerden dolayı sosyoekonomik açıdan oldukça önemli etkiler ortaya çıkarmaktadır. Gelişmiş ülkelerde 19. yy sonu itibariyle başlayan raylı sistem altyapı hizmetleri, ülkemizde ancak 20. yy sonlarına doğru hız kazanmıştır.

Kamu sektörü harcamaları yerel ve merkezi ölçekte incelendiğinde bütçelerin önemli bir kısmının ulaştırma sektörü ihtiyaçları için harcandığı görülecektir. Örneğin, İstanbul Büyükşehir Belediyesi, her yıl bütçesinin yaklaşık \%55-60'lık bir kısmını ulaştırma hizmetlerine harcamakta olup, bunun çok önemli bir kısmı da raylı sistemlere ayırmaktadır. Raylı sistem yatırımları, maliyet açısından oldukça yüksek bütçeler gerektirmektedir. Örneğin Türkiye'de bir metro hattnın ortalama km maliyeti 35 milyon EUR gibi düşünüldüğünde, bu kadar pahalı hizmet kararlarının doğru alınması önem taşımaktadır. Diğer taraftan kamu kaynaklarının sınırlı olması sebebiyle bu kadar büyük ölçekli yatırımların sadece kamu kaynakları ile hayata geçmesi oldukça zordur. Dolayısıyla metro yatrımları sebebiyle ortaya çıkan rantın bir şekilde kamuya döndürülmesi ve bu tür yatırımların finansmanında destekletici faktör olarak kullanııması amaçlanmalıdır. Bu çalışma kapsamında, metro hatlarının yapılmasıyla konut fiyatlarında ortaya çıkan değişimlerle ilgili çalışmaların literatür incelemesi amaçlanmaktadır.

Bu çerçevede akademik veri tabanlarından taranan yaklaşık 40 makalede ortaya çıkan sonuçlar yöntem, veri setleri ve bulguları yorumlanarak sunulmaktadır.

Amerika Birleşik Devletleri (A.B.D.) başta olmak üzere Avrupa, Uzak Doğu'da yer alan ekonomik anlamda dünyanın gelişmiş ülkelerinde metro istasyonları civarında yer alan gayrimenkul fiyatlarındaki değişmeler bilimsel açıdan incelenmiştir. Çoğunlukla kent içi raylı sistem yatırımlarının konut fiyatlarını artıracağı yönündeki teorik savlar ve amprik çalışmalar yoğun olmakla birlikte kent içi raylı sistem yatırımlarının farklı durum ve mekanlara değişik tepkiler yarattı̆ına ilişkin örnekler de bulunmaktadır. ${ }^{1}$

Daha önce de ifade edildiği gibi literatürde, kentiçi raylı sistem hatlarının genel olarak, gayrimenkul fiyatlarını artran yönde etkilediğine yönelik çalışmalara sıklıkla rastlanmaktadır. Ancak yine de raylı sistem hattının geçtiği bölgenin sosyoekonomik ve demografik özellikleri ile genel ulaşım ağı ekseninde şekillenen etkileri, her bir hat koridoru için konut fiyatları açısından değişiklik göstermektedir. Bununla birlikte konuya farklı bakış açıları ile yaklaşılarak aynı konu farklı düzlemlerde tartş̧ımıştır. Örneğin metro hatlarının farklı konut tipolojilerine veya farklı arazi kullanışlarını nasıl etkilediği araştırma konusu olmuştur. Bir başka bakış açısında ise metro hattının ortaya çıkardığı farklı

\footnotetext{
Wardrip, 2011, s. 1-12.
}

düzeydeki etkiler makro, mezo ve mikro düzeyde incelenmiştir (Beyazit, 2015). ${ }^{2}$ Efthymiou \& Antoniou ${ }^{3}$ tarafindan yapılan çalışmada ise, farklı ulaşım modlarının konut fiyatlarına ne şekilde yansıdığı araştırmıştır.

Bu çalışma, iki ana bölümden oluşmaktadır. Illkinde; konu ile ilgili literatür taramasının yöntemi ve bu tarama sonuncunda makalelerin, analiz/kategorizasyon biçimleri sunulmuştur. İkinci bölümde ise, incelenen makalelerden bazılarına özetle yer verilecek olup genel olarak belirlenen kategorilere ilişkin; örneğin metro hatlarının konut fiyatlarına etkisi ile ilgili yapılan çalışmaların daha çok hangi coğrafyalarda ve neden irdelendiği, hangi yöntemlerin izlendiği ve ne tür bulgulara ulaşıldığı ile ilgili değerlendirmeler sunulacaktır.

\section{Yöntem}

Bu çalışma kapsamında, metro hatlarının konut fiyatlarına etkisi ile ilgili yapılan makale taramasında akademisyenlerin ve profesyonellerin kayda değer katkılar yaptığı ve konunun derinleşmesinde pay sahibi oldukları görülmüştür. Bu araştırma; akademik dergilerde yayınlanmış makaleleri analiz etmektedir. Bunun için içerik analizi yöntemi kullanılmıştır. Çalışmaya konu olan makalelerin saptanması sürecinde şu kriterleri sağlayan makaleler dikkate alınmıştır:

- Sadece bilimsel değerlendirme sürecinden geçmiş makaleler

- Doğrudan ve İngilizce olarak "metro lines (metro hatları), railway lines (raylı sistem hatları), value capture (değer yaratma), real estate value (gayrimenkul değeri), land price (arazi fiyat), hedonic price modelling (hedonik fiyat modeli)" kelimeleri ile tarama yapıldığında rastlanan makaleler

Makalelerin sınırlandırıması için aşağıda sunulan kriterler saptanmış ve bunlara dahil olmayanlar çalışmanın dışında bırakılmıştır: Kitaplar, kitaplardaki bölümler ve konferans bildirileri ve baş yazılar (editorial). Bunlar dışında elektronik olarak erişimi mümkün olmayan makaleler de araştrmaya dahil edilmemiştir. Araştırmada Yıldız Teknik Üniversitesi'nin elektronik veri tabanları kullanılarak tarama yapılmıştr. Sciencedirect, Scopus, Ebsco, Proquest Global, Emerald, Springerlink veri tabanları en çok yayın ile karşılaşılan veri tabanlarıdır. Literatür taramasında, ağırlıkIı olarak 2000 yılı sonrasındaki yeni çalışmaların olmasına dikkat edilmiştir. Özellikle asya/uzak doğu ülkelerindeki altyapısal ve finansal gelişmelerle ilgili konuların bugünkü bilim dünyasına yayın olarak katkıda bulunması büyük oranda 2000 'li yılların sonrasında gerçekleşmiştir. Diğer ülkelerde de bu alanda gelişmeler 2000'li yıllarda ağıllık kazandığı için böyle bir tercih yapılmıştı. Diğer taraftan

\footnotetext{
Beyazit, 2015, s. 12-23.

3 Efthymiou \& Antoniou, 2013, 1-22.
} 
farklı veri tabanlarında aynı makaleler ile karşılaşııması durumunda tekrar olmamasına dikkat edilmiştir.

Araştırmanın yöntemi ve kapsamın saptanmasında; konuyla ilgili akademik dergilerin tamamında makaleler taranmıştır. Makale taramasında; (1) başıı, (2) anahtar kelimeler ve (3) özet taranmıştr. Sonuç olarak incelenen makale sayısı 40'dır ve literatür taramasında da görüleceği üzere genel olarak ulaştırma altyapılarının arazi değerlerine etkisi ile ilgili farklı bakış açısı ve yaklaşımları içeren çalışmalar özetle Tablo 1'de sunulmaktadır.

İçerik analizinin prosedürünün saptanmasında ise şöyle bir değerlendirme yapılmıştır: İ̧̧erik analizi için belli kodlar verilmiş ve bir matris tablo oluşturulmuştur. Kodlar şu şekilde saptanmıştır:

- Kaynakça verileri (yazar/yazarlar, başlık, yayın yılı ve dergi adı

- Kullanılan yöntem (çalışmanın türü, kapsadığı zaman, kullanılan yöntem ve kullanılan analizler

- Ampirik bağlam (üzerinde çalışılan şehirler, coğrafi dağılımı, örneklem türleri/birimleri)

İçeriğin netleştirilmesi için yazarların odak noktaları, tartışma konuları, araştırma soruları, metodolojileri ve çalışmanın ana yapısını ortaya koymak için tüm makaleler okunmuştur. Her makalenin odaklandığı çerçeve ortaya konmuştur. Tanımlayıcı tartışmalardan önceliklendirilmiş açılımlar ortaya konmuştur.

\section{Analiz/Literatür Taraması}

Ulaştırma ile kentsel mekanın şekillenmesi konuları, kentsel ekonomi çerçevesinde tartşılan konular arasındadır. Ulaştırma altyapı yatırımları yer seçimi ve kentsel büyümeyi yönlendirme açısından güçlü etkiye sahiptir. Ayrıca, ulaştırma altyapıları; arazi değerleri üzerinde etkili olmakta, yaşanabilirliği olumlu yönde etkilemekte ve yeni yerleşim yerlerinin inşası açısından da önemli etki yapmaktadır. ${ }^{4}$ Yankaya \& Çelik ${ }^{5}$ ulaştırma altyapı seviyesinin, ülkenin gelişmişlik düzeyi açısından da bir gösterge niteliği taşıdığına işaret etmiştir. Yatırımların bazen mevcut kapasitelerin ihyasını içerirken bazen de yeni yerleşim bölgelerine erişim imkanı sağlamaya veya kentsel gelişmeyi yönlendirmeye yaradığına değinilmiştir. Dolayısıyla ulaştırma altyapılarının verimliliği ile ilgili konular öteden beri araştrmacıların ilgisini çeken konular arasında yerini bulmaktadır. Bu yatırımların etkileri (sanayi, ticaret, ofis ve değişik konut alanları gibi) farklı kentsel sektörlerde gelir, istihdam, nüfus, arazi kullanış, yoğunluk ve parasal değerlerde meydana gelen değişimler perspektifinden, kısa ve uzun dönemli etkiler planlama ve ulaşım literatüründe yoğun olarak çalışıldığı ifade edilerek konunun farklı düzlemlerde çok değişik bakış açıları ile ele alındığı dile getirilmiştir.

\footnotetext{
${ }^{4}$ Ge, Macdonald ve Ghosh, 2012. $\quad{ }^{5}$ Yankaya \& Çelik, 2005, s. 61-79
}

Kentsel ekonomi ile ilgili teorik çalışmalarda, özellikle Alonso ${ }^{6}$ tarafindan öngörülen tek merkezli kent modellemesinde, bütün istihdamın kent merkezinde yer aldığı varsayılmaktadır. Bu durumda, ev ile iş arasında gidip gelme zamanındaki değişim, kent rant eğrisinin önemli bir belirleyicisi olmaktadır. Ev-iş arasında gidip gelme zamanında oluşan tasarruflar kent toprağı rantına yansımaktadır. Buna göre en yüksek rant merkezdedir çünkü kent merkezinde ulaşım maliyeti en düşüktür. En düşük rant da kent çeperindedir. Bu durumda bireyler fayda fonksiyonuna bağı olarak, merkezle çeper arasında yer seçimi yapmaktadır ve tüm bireylerin faydaları diferansiyel ranta bağı olarak eşittir. Bu modeller, her ne kadar basit ve stilize olursa olsun, kentsel rantın, ulaşım maliyetiyle olan temel ilişkisinin anlaşılmasına yardımcı olmaktadır.

Raylı sistem yatırımları asıl olarak ulaştırma hizmetine katkı sunmayı amaçlamakla birlikte ulaştırma dışında başka faydalar da üretmektedir. Sadece ulaşım eksenli olmayan bu katkılar özellikle gelişmiş ülkelerde araştırma konusu olarak çalışılmaktadır.

Banister \& Goodwin ${ }^{7}$ tarafindan yapılan çalışmada raylı sistemlerin yarattı̆ı etkiler üç farklı düzeyde ele alınmaktadır. Bunlardan ilki üst perdede makroekonomik düzeyde ele alınabilecek üretim, nüfus, istihdam ekonomik büyüme gibi faktörlerdir. Orta kademede beliren etkiler, daha çok sektörel düzeyde hissedilmektedir. Örneğin artan erişilebilirlik sebebiyle firmaların raylı sistem koridoru boyunca kümelenmeleri, iş gücü piyasasının kuvvetlenmesi, sektörler arası bütünleşme ve etkileşime katkıda bulunması veya $\mathrm{CO}_{2}$ çevresel etkileri azaltması orta düzeyli etkiler arasındadır. En küçük düzeyli etki ise gayrimenkul fiyatlarındaki değişimler olarak ele alınmaktadır. Buna göre artan erişilebilirlik sebebiyle düşen ulaşım maliyetleri ve zaman kazançları gayrimenkul fiyatlarına yansımaktadır.

İstanbul metrosunun yarattğı ekonomik etkiyle ilgili çaış̧ma benzer bakış açısı ile Beyazit ${ }^{8}$ tarafindan yapılmıştır. Bu çalışmada (1) nüfus ve istihdam: "büyük düzeyli ekonomik etkiler", (2)metro koridoru etrafinda firmaların kümelenmesi, yeni firmaların açılması gibi sektörel etkiler "orta düzeyli ekonomik etkiler", (3) gayrimenkul fiyatlarının değişimi gibi etkiler ise "küçük düzeyli ekonomik etkiler" kategorilerinde incelenmiştir. Buna göre İstanbul metrosunun büyük ölçekte nüfus ve istihdam açısından herhangi bir fayda üretmediği tespit edilmiştir. Bununla birlikte orta düzeyli etkiler açısından ise sektörel değişmelere ve dönüşümlere önemli katkılarda bulunduğu aynı zamanda yeni yatırımları teşvik ettiği ve bir bakıma sektörel şekillenmenin metro koridoru etrafinda gerçekleştiği sonucuna ulaşılmıştır. Diğer taraftan İstanbul metrosunun gayrimenkul fiyatlarına, büyük etkiler oluşturmadığı değerlendirilmiş

\footnotetext{
6 Alonso, 1964. 223.

Banister \& Goodwin, 2011, s. 212- ${ }^{8}$ Beyazit, 2015, s. 12-23.
} 


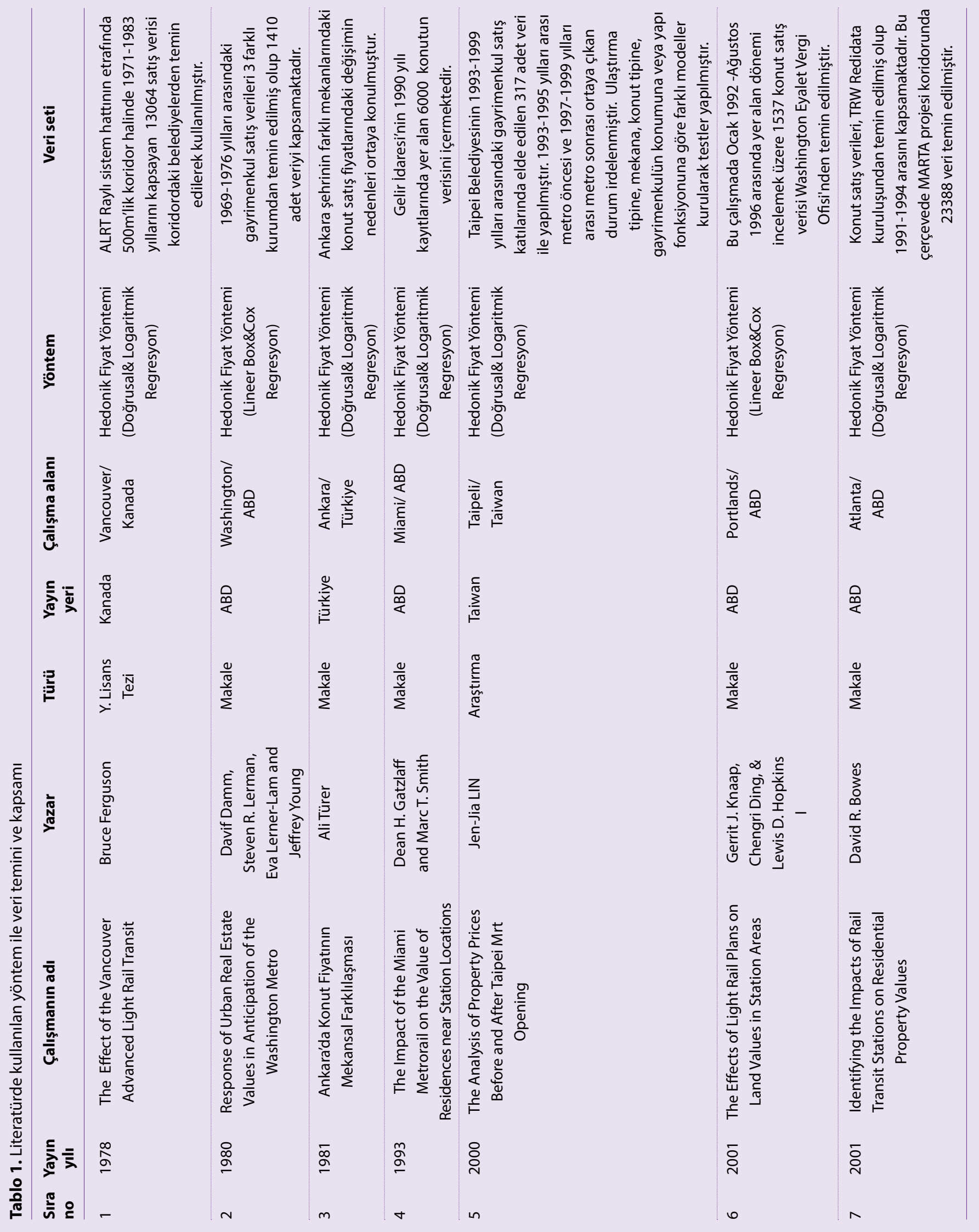




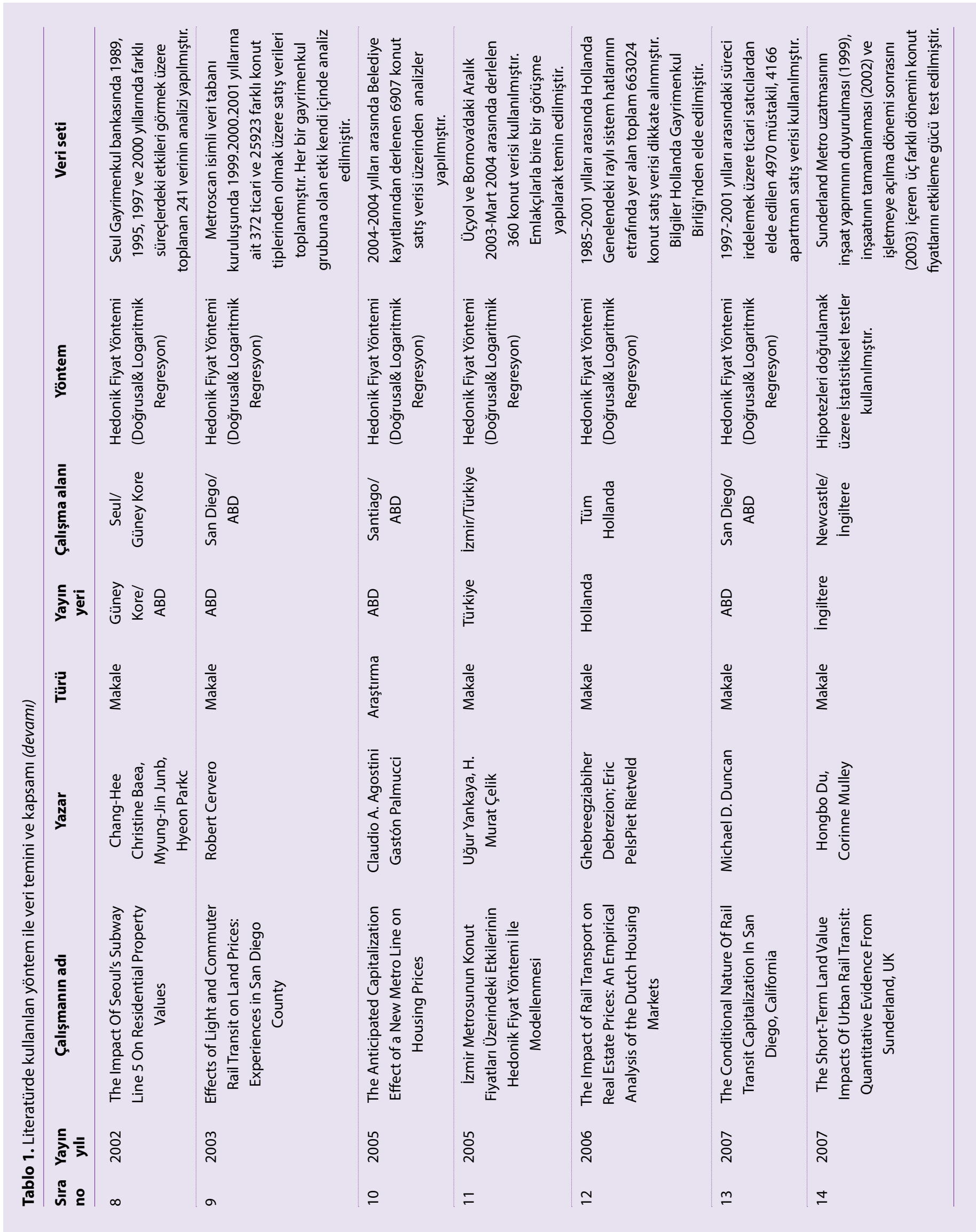




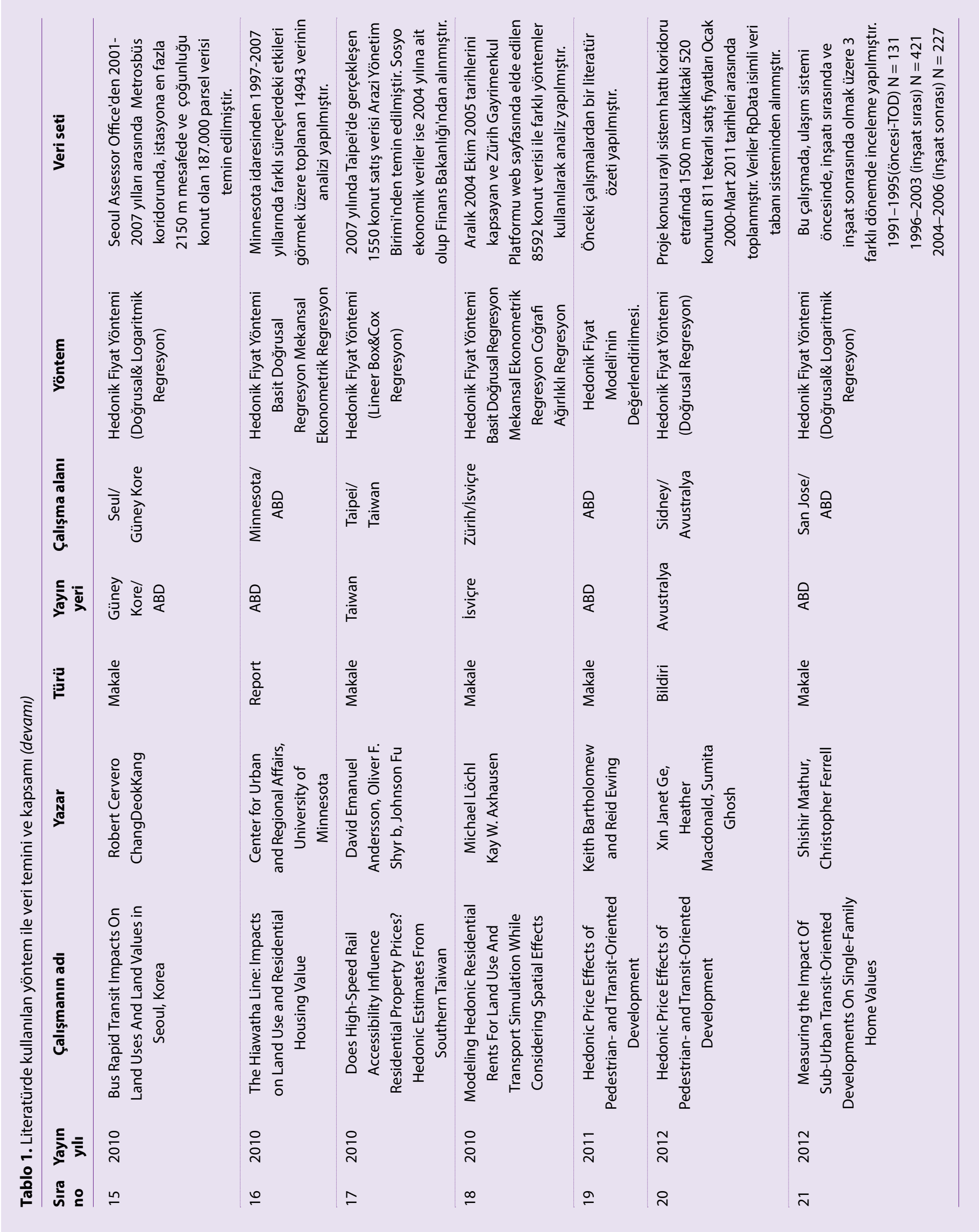




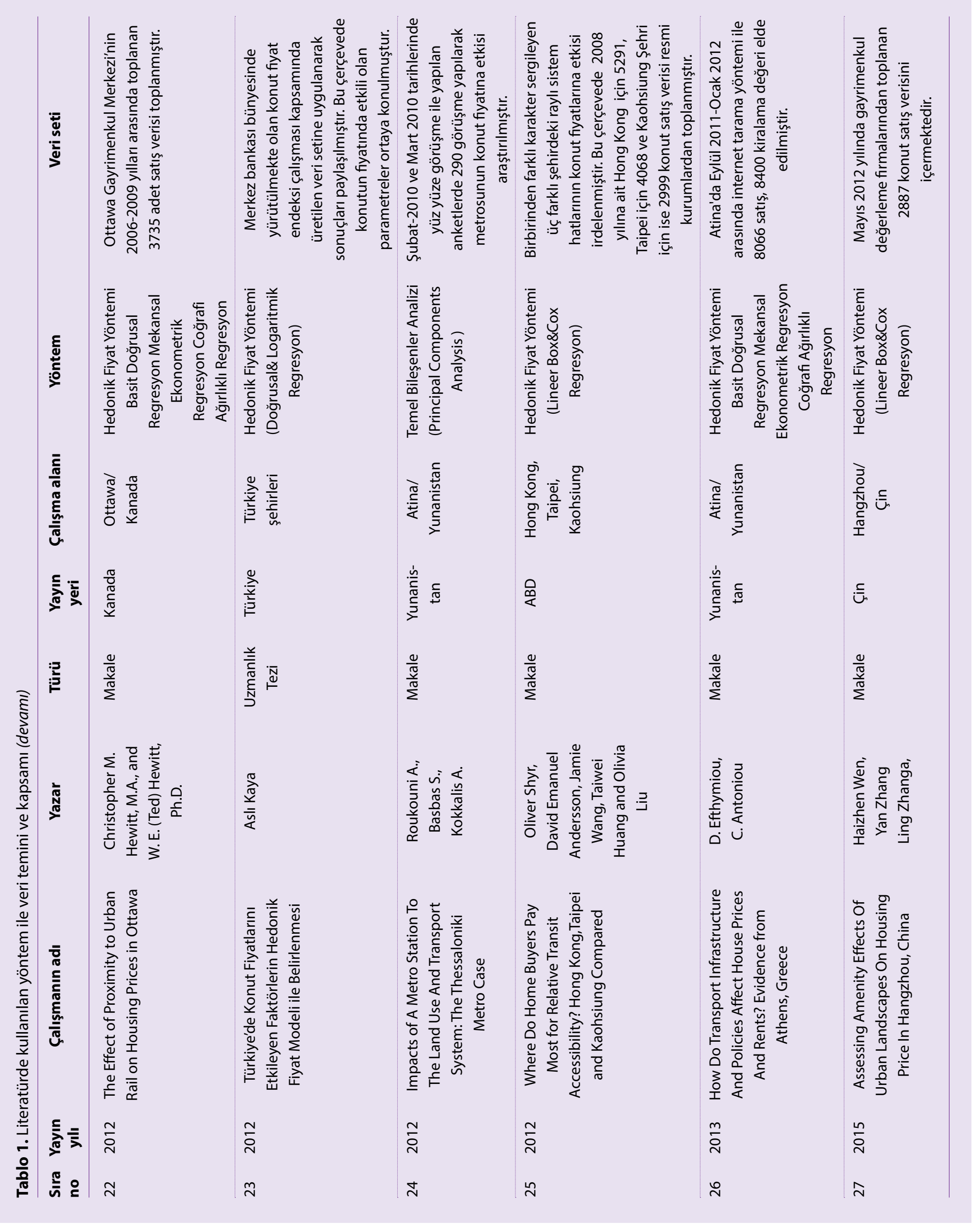




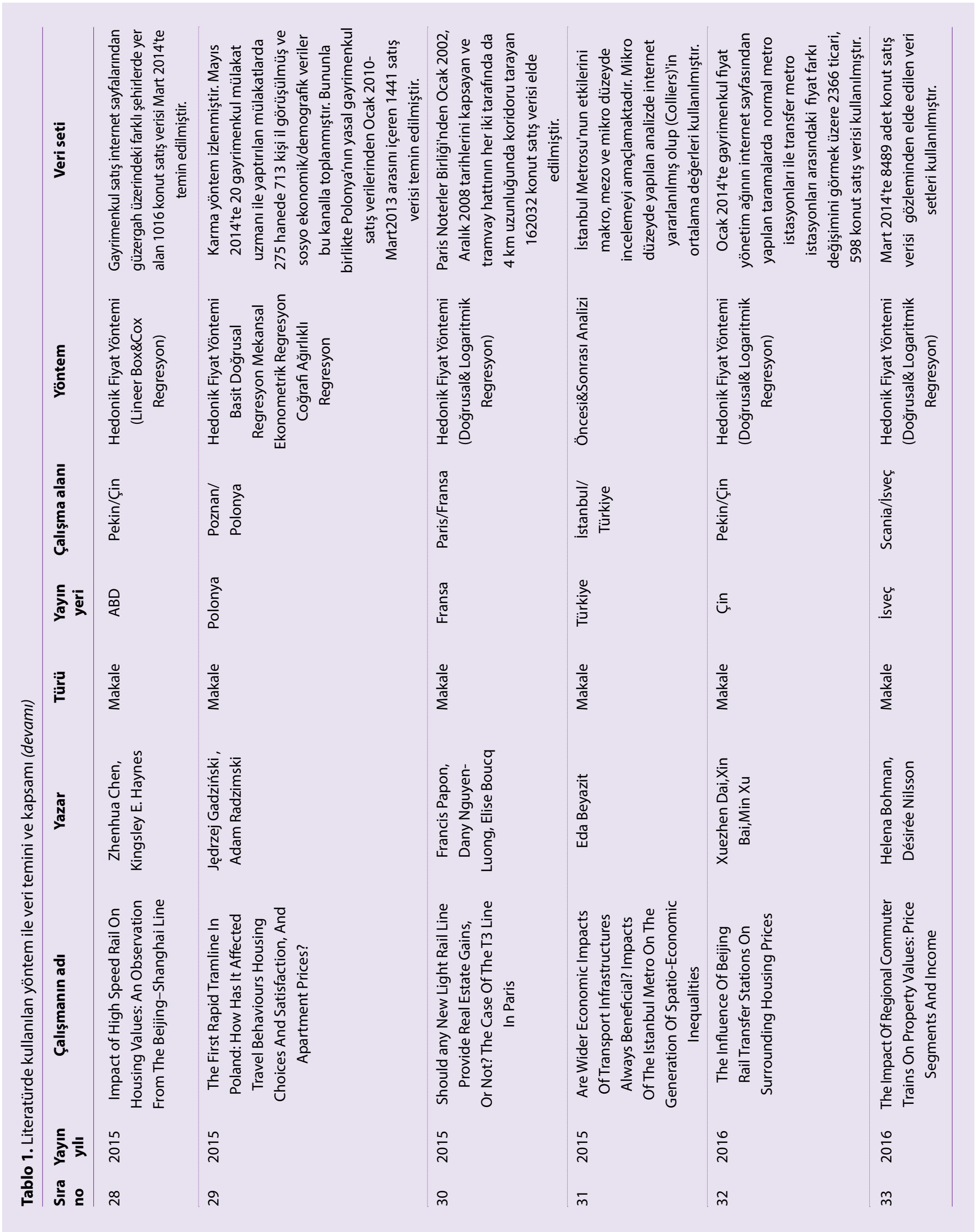




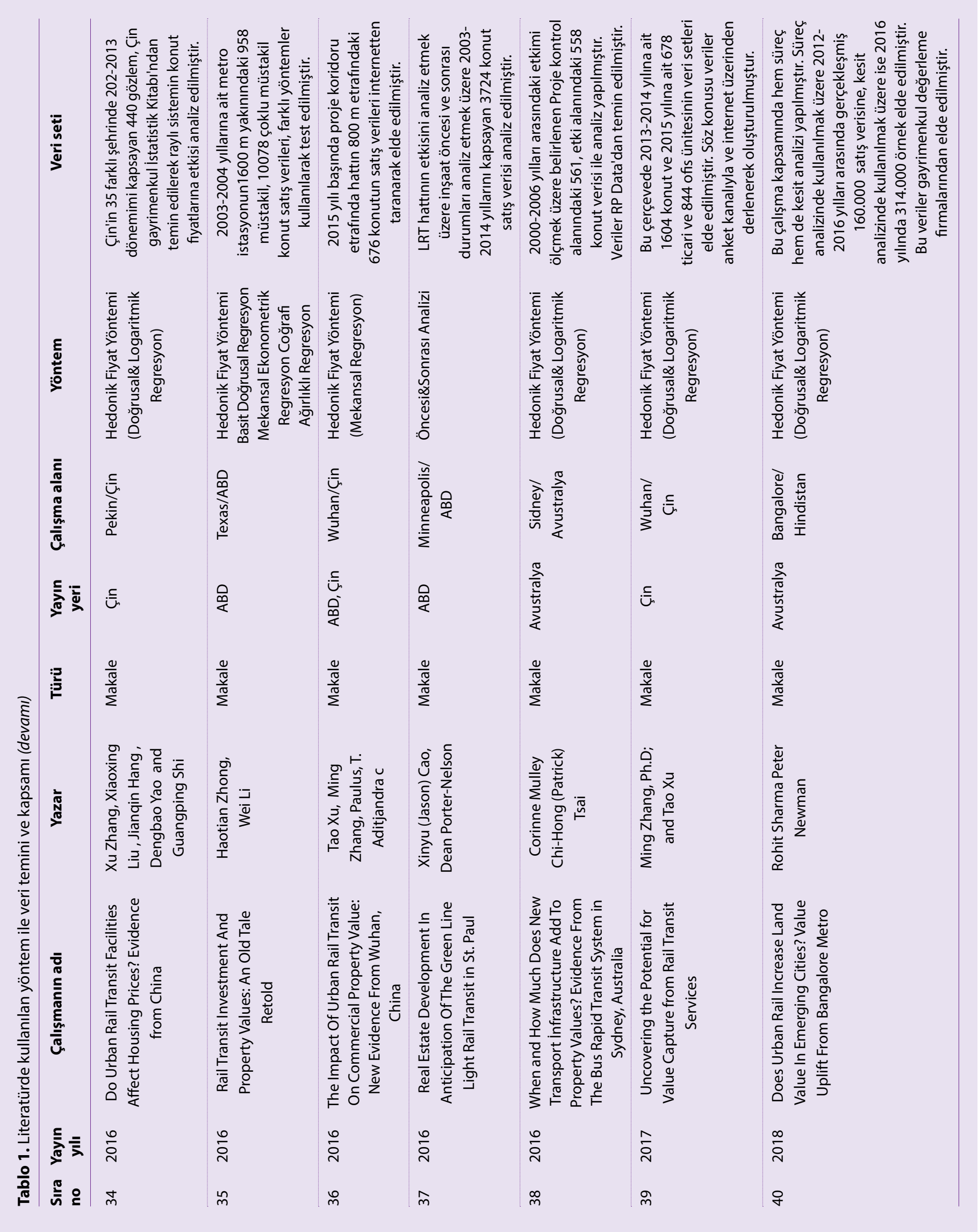


olup, bununla birlikte sosyoekonomik olarak az gelişmiş bölgelerdeki konut fiyatlarının metro altyapısına daha duyarlı olduğu vurgulanmıştır.

Türkiye'de ulaştırma altyapı yatırımlarının gayrimenkul fiyatlarına etkisi ile ilgili çalışmalar oldukça sınırlıdır. Bunun en önemli sebebi özellikle raylı sistem altyapısı hizmetlerinin sadece 30 yıllık bir geçmişi olmasıdır. Bu çerçevede ülkemizde raylı sistem yatırımlarının konut fiyatlarına etkisiyle ilgili ilk araştrrmalardan biri olan ve İzmir Metrosu'nun konut fiyatlarına etkileri ile ilgili ilk çalışma Yankaya \& Çelik $^{9}$ tarafindan yapılmıştı. Bu çalışmada $11,5 \mathrm{~km}$ uzunluğunda ve 10 istasyona sahip olan İzmir metrosunun geçtiği Üçyol ve Bornona semtlerindeki konut fiyatlarının nasıl etkilendiği irdelemiştir. Bu çalışmanın ana bulgusu, en yakın metro istasyonuna olan yürüme mesafesinin fiyat ile negatif ilişkisi ve bu ilişkinin bütün denklemlerde yüksek anlam düzeyine sahip olduğu ifade edilmektedir. Buna göre, metro istasyonuna uzaklık açısından apartman daire fiyat her 100 metre yakınlaştikça tüm proje alanında 476 USD, Bornova'da 519 USD ve Üçyolda 1870 USD daha artmaktadır. Bu durum Yankaya \& Çelik ${ }^{10}$ tarafindan iki şekilde açıklanmaktadır: (1) Üçyol bölgesi mekansal yapısı itibariyle, metro istasyonu etrafinda daha toplanmış (kompakt) bir yerleşmedir. (2) Üçyol bölgesindeki metro kullanımı diğer alanlarına göre, daha fazladır.

2012 yılında işletmeye açılan ve İstanbul'un Anadolu yakasında hizmet veren Kadıköy-Kartal metrosunun konut fiyatlarına etkisi ile ilgili bir araştırma da İnanoğlu'nun (2014) Yüksek Lisans tezinde çalışılmıştır. Konut endeks değerlerinin yıllık ortalamaları kullanılarak yapılan analizlerde, ele alınan dönemde ulaşımdan daha etkili faktörlerin varlığı değerlendirilmiştir. Acıbadem, Aydınevler, Altayçeşme, Bağlarbaşı, Küçükyalı ve Zümrütevler mahalleleri ile ilgili 2008-2013 yılları arasındanki konut fiyat değişim endeksleri REIDIN.com firmasının verilerinden oluşturulmuştur. Sabit endeks yöntemi ile Kadıköy-Kartal metrosunun 2008-2013 yılları arasındaki konut fiyatlarına etkisi değerlendirildiğinde, metrodan kaynaklı bir değer artışı olduğu tespit edilememiştir.

İstanbul özelinde ulaştırma altyapılarının konut fiyatına etkisi açısından yapılan bir başka çalışmada ise Eryılmaz ${ }^{11}$ TEM Otoyolu İstanbul Anadolu Kesimi kavşak kolları etrafindaki konut fiyatlarındaki değişimi incelemiştir. Çalışma kapsamında ulaşım yatırımı ile arazi değer artışı arasındaki ilişkiyi ve arazi değer artışının ulaşım yatırımlarının oluşturduğu getiriyi, çevreye verdiği zararları, kentsel planlamada ulaşım kararlarının etkisini, ulaştırma yatırımlarının kentte yaşayanların tümünün yararını öncelikli olarak ele alınmaSı ve bu yatrımların finansmanında uygulanabilecek metotlar değerlendirilmiştir. Bu amaçla, 1985 ile 2006 yılları

\footnotetext{
9 Yankaya \& Çelik, 2005, s. 61-79.

${ }^{11}$ Eryılmaz, 2013.

${ }^{10}$ Yankaya \& Çelik, 2005, s. 61-79.
}

arası için, kamulaştırma takdir değerleri, kamulaştrma bedellerine itiraz davalarının sonuç değerleri ve rayiç bedellerine ilişkin veriler kullanılmıştır. Eryılmaz'ın ${ }^{12}$ çalışmasında TEM'deki kavşakların çevresindeki etki alanı belirlenmiştir. 1. bölge olarak tanımlanan $1,0 \mathrm{~km}$. alan içindeki bölgelerde $126 \mathrm{TL} / \mathrm{m}^{2}$, 2. bölge olarak tanımlanan $1,0 \mathrm{~km}$ ile $2,0 \mathrm{~km}$ arasındaki bölgelerde $67 \mathrm{TL} / \mathrm{m}^{2}$ ve 3 . bölge olarak tanımlanan 2,0 km ile 3,0 km arasındaki bölgelerde ise $59 \mathrm{TL} /$ $\mathrm{m}^{2}$ 'lik ortalama fiyat artşları olmuştur. Samandıra kavşağı hariç, ortalama fiyatlar 1. bölgede $\% 760$, 2. bölgede $\% 357$, 3. bölgede $\% 222$ oranlarında artı̧ göstermiştir. Eryılmaz, ${ }^{13}$ kavşak merkezlerine yakınlık, arazi değer artı̧larına baskın şekilde etken olduğu sonucuna ulaşmıştır.

Daha önce de ifade edildiği gibi, dünyada 1900 'lü yıllarla başlayan raylı sistem yatırımlarının etkileri $1950^{\prime}$ li yıllardan itibaren araştırmacılar açısından merak konusu olmaya başlamıştır. Kentsel ekonominin önemli bir bileşeni olan gayrimenkul sektörüne yansıyan etkiler de benzer yıllarda irdelenmeye başlanmıştır. Amerika Birleşik Devletleri (A.B.D.) başta olmak üzere, Avrupa ve Uzak Doğu'da yer alan ekonomik anlamda dünyanın gelişmiş ülkelerinde metro istasyonları civarında yer alan gayrimenkul fiyatlarındaki değişmeler birçok örnekle incelenmiştir.

Efthymiou \& Antoniou ${ }^{14}$ tarafindan yapılan çalışmada, Atina'da farklı ulaşım modlarından oluşan ulaştırma altyapı ve politikalarının konut kira ve satış fiyatlarını doğrudan veya dolaylı olarak nasıl etkilediği ile ilgili bir araştırma yapılmıştır. Araştırma kapsamında derlenen kiralama ve satış verileri doğrusal regresyon, mekansal ekonometrik model, coğrafi ağırlıklı regresyon yöntemleriyle ortaya çıkan sonuçlar değerlendirilmiştir. Analiz sonuçlarına göre, farklı ulaşım altyapılarının konut fiyatlarında farklı etkiler yaratthğı gözlemlenmiştir. Metro, tramvay, banliyö veya otobüs gibi ulaşım araçları, erişibilirlik marifetiyle konut fiyatlarını artıran, şehirlerarası gar, deniz ve hava limanı gibi altyapılar ise gürültü gibi negatif dışsallıklar sebebiyle konut fiyatlarını azaltan etkiler yaratmıştır. Örneğin metro hattının 500 m civarında yer alan konutların satıs değeri \%6,75$\% 11,66$, kiralama fiyatları ise $\% 4,2-\% 6,21$ düzeyinde daha yüksek bulunmuştur. Diğer taraftan eski tren hatlarının yer aldığı garın $500 \mathrm{~m}$ civarınsa ise konut satış fiyatları $-\% 10,2$ ile $-\% 12,24$, kiralama fiyatları ise $-\% 1,55$ ile $-\% 1,73$ daha düşük bulunmuştur. Bu sonuçlar göstermektedir ki, konut fiyatları farklı ulaşım modlarının ürettiği pozitif veya negatif dışsallıklardan doğrudan etkilenmekte olup bu çerçevede oldukça esnek davranış sergileyebilmektedir.

Raylı sistemlerin konut fiyatlarına etkisi ile ilgili farklı bir çalışma da Avustralya'nın Sidney kentinde olimpiyatlardan sonra inşa edilen metro hattında yapılmıştı. GE, Macdonald ve Ghosh ${ }^{15}$ tarafindan yapılan araştirma sonuçları il-

\footnotetext{
12 Eryılmaz, 2013

${ }^{13}$ Eryılmaz, 2013

${ }^{14}$ Efthymiou \& Antoniou, 2013, 1-22.

${ }^{15} \mathrm{Ge}$, Macdonald ve Ghosh, 2012.
} 
ginç bulgular ortaya çıkarmıştır. Çalışma kapsamında, bahse konu metro hatt üzerindeki istasyonunun $1,5 \mathrm{~km}$ çapındaki etki alanındaki konutların satış fiyatları incelenmiştir. ÇaIışma kapsamında proje konusu raylı sistem hatt koridoru etrafinda 1500 m uzaklıktaki 520 konutun 811 tekrarlı satış fiyatları Ocak 2000-Mart 2011 tarihleri arasında toplanmıştr. Veriler RpData isimli veri tabanı sisteminden alınmıştır. Metro inşaatına başlamadan önceki 2000-2002 yılları, inşaatın başlamasından sonraki 2002-2004 yılları, inşaat bitmeden önceki 2004-2007 yılları ve son olarak hattın işletmeye açılmasından sonraki 2009-2011 yıllarını kapsayan dört farklı dönemi irdelenmiştir. Buna göre raylı sistemin yapılacağı duyurulduğunda ve işletmeye açıldıktan sonra konut fiyatlarında anlamlı artışlar olduğu, diğer taraftan inşaat bitene kadar raylı sistem yatırımının konut fiyatlarını negatif yönde etkilediği değerlendirilmiştir. Bir başka deyişle, raylı sistem işletmeye açıldıktan sonra etki alanındaki konut fiyatlarında ortalama olarak 58,460 AUD (Avustralya Doları) artış olmuştur, buna karşın inşaatın başlamasıyla birlikte yine raylı sistemin etki alanındaki konut fiyatlarında ortalama 21,098 AUD düşüş olmuştur. Bu sonuçlar litearatürdeki diğer bulgulara göre oldukça baskın görünmektedir. Bunun bir sebebi Sindey'de benzin ve otopark fiyatlarının yüksek olmasından dolayı merkeze gelen yolcuların raylı sistemi tercih etmeleridir. Diğer bir etken de, gayrimenkul sahiplerinin raylı sistemin tetiklemesiyle, bulundukları bölgenin sosyo-ekonomik olarak güçleneceğini düşünmeleri ve bu çerçevede hareket ettikleri şeklinde izah edilebilir. ${ }^{16}$

Raylı sistem yatırımlarının dönemsel etkileriyle ilgili bir başka çalışma da ABD'nin Mineapolis kentindeki Green Line LRT projesi için yapılmıştır. Çalışma kapsamında hatla ilgili ilk mühendislik çalışmalarının duyurulması ve finansman işlemlerinin tamamlanıp ihalenin ilana çıkması şeklinde iki farklı zaman milat olarak kabul edilmiştir. Bu çerçevede raylı sistemin etki alanındaki yapıların inşaat ruhsat sayıları ve ruhsat bedellleri çok değişkenli bir regresyon modeliyle test edilmiştir. ${ }^{17} 7049$ ruhsat verisi ile yapılan çalışmada mühendislik çalışmalarıyla ilgili reklamların ruhsat sayılarını veya bedellerini artıran bir etki oluşturmadığı belirtilmiştir. Diğer taraftan projeyle ilgili finansman bulunması ve ihale ilanına çıkılması ise bina ruhsat sayılarında $\% 24$, ruhsat bedellerinde ise \%80 artşa neden olmuştur (Cao \& Nelson, 2016). Bir başya deyişle proje finansmanının sağlanarak projenin yapımıyla ilgili ciddi bir gelişme olması hattın etki alanındaki bina ruhsat sayılarının artmasıyla sonuçlanmıştr. Makalede, herhangi bölgedeki bina ruhsat sayısındaki artışların bölgedeki gelişmelerle ilgili önemli ipuçlar verdiği, arazi gelişiminin ruhsat sayısına paralel olduğu ifade edilmiştir.

Metro hatlarının konut fiyatlarına etkisi ile ilgili farklı bir yaklaşım da istasyon tipolojisi üzerinde incelenmiştir.

\footnotetext{
${ }^{16} \mathrm{Ge}$, Macdonald ve Ghosh, 2012. $\quad{ }^{17}$ Cao \& Nelson, 2016, s. 24-32.
}

Çin'in başketi Pekin'de metro hatları ulaşım ağının ana omurgasını oluşturmaktadır. Pekin'de 1953'de planlama çalışmaları başlamış ilk metro hatt 1971 yılında açılmıştır. 2014 yılı itibariyle Pekin'de 17 metro hatt işletme altında olup, 40'ı aktarma merkezi olmak üzere toplam 273 istasyonla hizmet verilmektedir. Çalışmada, 2010-2014 yılları arasında hizmete açılan 10 metro hattından 122 istasyon etrafinda yer alan konutların satış fiyat değişimleri, 2000 $\mathrm{m}$ yarıçap dahilinde incelenmiştir. Çalışmada kullanılan veriler, "Pekin Gayrimenkul Satş Yönetimi Sitesi" nden temin edilmiştir. Buna göre $598^{\prime} i$ transfer merkezi etrafinda olmak üzere toplam 2965 konutun satş fiyat ve konutlara ilişkin karakteristik özellikleri derlenmiştir. ${ }^{18}$

Dai, Bai ve $\mathrm{Xu}^{19}$ tarafindan yapılan araştırma bulguları transfer istasyonlar ile normal istasyonların konut fiyatlarına farklı etkiler yarattğını göstermektedir. Birinci olarak transfer istasyonları 1200-1400 m yarıçapında etkili iken, normal istasyonlar $1000 \mathrm{~m}$ civarında etkisini kaybetmektedir. İkinci olarak ise transfer istasyonları daha fazla olmak üzere her iki istasyon tipi de etki alanındaki konut fiyatlarını ortalama olarak artırmaktadır. Örneğin transfer istasyonlarında istasyona her $100 \mathrm{~m}$ yakınlaştikça konut fiyatları 96,5 yuan $/ \mathrm{m}^{2}$ artmaktadır. Bununla birlikte diğer faktörler izole edildiğinde, transfer istasyonu civarındaki ortalama fiyatlar normal istasyona göre 3368,16 yuan $/ \mathrm{m}^{2}$ daha yüksek geçekleşmiştir. Çalışmanın üçüncü temel bulgusu, hem transfer hem de normal istasyonlarda özellikle ilk 200 m yarıçap menzilinde negatif dışsallıklar konut fiyatlarını azaltmakta ancak genel değerlendirme yapıldığında; raylı sistem istasyonu etrafindaki konutların fiyatları artı̧ göstermektedir. Son olarak metro istasyonları, konut fiyatları açısından banliyö kesiminde merkeze göre daha büyük etkiler ortaya çıkarmaktadır.

Paris'te 2006 yılında işletmeye açılan bir tramvay hattının konut fiyatlarına etkisi çalışılmıştır. Söz konusu yayının daha önce benzer konuda başka hatlar için IAU Ile-deFrance ve IFSTTAR tarafindan yapılan çalışmaların devamı niteliğinde olması amaçlanmıştı. Bu tür yayınların yapılmasındaki bir başka amaç da, raylı sistem sebebiyle oluşan rantın, vergi yoluyla kamuya dönüşünü sağlayarak diğer ulaştırma yatırımlarını finanse etmesiyle ilgili tartışmalara esas oluşturma niyeti taşımasıdır. ${ }^{20}$ Çalışma alanı, tramvay hattının her iki tarafinda 400 m'lik bantlar çerçevesinde güzergahın 4 km'lik kesimi ile sınırlandırılmıştı. Araştırmanın verileri Paris Noter Odası'ndan temin edilmiş olup 1 Ocak 2002-31 Aralık 2008 arasında yani tramvayın açılışından önceki beş yılı ve sonraki iki yılı kapsamaktadır. 162.032 konutun satış veya el değiştirme verilerini içermektedir. Veriler GIS yazılımı ile koordinatlandırılmıştır ve konutların karakteristik bilgilerini de içermektedir. Yöntem açısından

\footnotetext{
${ }^{18}$ Dai, Bail ve $\mathrm{Xu}, 2016$, s. 79-88.

${ }^{19}$ Dai, Bail ve Xu, 2016, s. 79-88.

${ }^{20}$ Papon, Nguyen ve Boucq, 2015 s. 43-54.
} 
bu çalışmada da Rosen'in ${ }^{21}$ hedonik fiyat modeli prensipleri esas alınarak Box-Cox formu kullanılmıştır. ${ }^{22}$ Paris, T3 tramvayının konut fiyatlarına etkisi ile ilgili yapılan araştırmada sekiz faktörün konut fiyatlarını tetiklediği tespit edilmiştir. Bunlar; (1) Ulaşım altyapısının tipi (metro, tramvay, ayrılmış otobüs yolu vs.), (2) Ulaşım altyapısınından önceki mevcut ulaştirma kurgusu, (3) Gayrimenkullerin hatta veya istasyona olan mesafesi, (4) Konut tipleri apartman/müstakil (özellikle şehrin çeperlerinde), (5) Yerel karakteristikler (sosyal ve demografik yapı, tarihi durum, yoğunluk vs), (6) Altyapı inşaat sırasında bölgenin ihyasıyla ilgili gelişmeler, (7) Genel gayrimenkul piyasa eğilimleri ve (8) Araştırmanın yapıldığı dönem (inşaat öncesi, inşaat sırası veya işletme aşamasında).

Sonuç olarak T3 tramvayının 200 m-400 m etrafindaki konut fiyatlarında $\% 5$ oranında bir artş tespit edilmiştir ancak bu değer reel olarak sıfirın çok üzerinde değildir. Hatta istasyon erişilebilirliği sebebiyle 2002, 2005 ve 2007 yıllarında küçük te olsa bir düşüş tespit edilmiştir. Bu sebeple çalışmaya göre elde edilen veriler çerçevesinde, T3 hattının konut fiyatlarına nasıl bir etki yaptı̆ına ilişkin kesin ve net bulgulara ulaşmak mümkün olmamıştır. ${ }^{23}$

Mulley \& Hong Tsai ${ }^{24}$ altyapı hizmeti yatrım maliyetlerinin yine altyapıdan kaynaklı gayrimenkul değer artışı ile finansmanı konusunda yapılan tartş̧maları Liverpool-Parramatta Transitway (LPT) metrobüs hatt çerçevesinde ele almıştr. Metrobüs güzergah koridoru boyunca $400 \mathrm{~m}$ yarıçap dahilinde ve 2000-2006 yılları arasında gerçekleşen 1119 konut satiş verisi çok katmanlı hedonik model (multilevel hedonic model) ile test edilmiştir. Buna göre işletmenin açılmasından hemen sonraki 2003-2004 yıllarında çalışma alanı içindeki konut fiyatlarında ortalama olarak \%11 oranında değer artışı meydana gelmiştir. Bu değer arţşında, metrobüs hattının geçtiği koridorun karakteristik özeliklerinin de etkin olduğu tespit edilmiştir. Metrobüs projesi, ulaşım altyapısı açısından zayıf olan şehrin banliyösüne hizmet ettiğinden, o bölgede yaşayanların altyapıyla ilgili duyarlı ve fiyatları artırmaya istekli davranışlar sergilemesine sebep olmuştur (Mulley \& Hong Tsai, 2016).

Yine Du \& Mulley'in ${ }^{25}$ bir başka çalışmasında Newcastle'da bulunan Tyne ve Wear Metrosu kapsamında gayrimenkul fiyatlarının değişimi incelenmiştir. Bu çerçevede metro istasyonlarının $1000 \mathrm{~m}$ civarındaki konutlar basit endeks ve bazı basit regresyon denklemleriyle test edilmiştir. Sonuçlar metro hattının konut fiyatlarını artırmadığını göstermiştir. Erişebilirliğin konut fiyatını etkileyen faktörlerden biri olduğu, dolayısıyla literatürün aksine bazen konut fiyatlarını arttran yönde etki yapmayacağı değerlendirilmiştir. Diğer

\footnotetext{
${ }^{21}$ Rosen, 1974, s. 34-55.

43-54.

22 Papon, Nguyen ve Boucq, 2015 s. ${ }^{24}$ Mulley \& Hong Tsai, 2018, 3-10.

43-54.

${ }^{23}$ Papon, Nguyen ve Boucq, 2015 s.
}

taraftan arazi kullanım kararları, makroekonomik göstergeler, sosyo fiziksel durum gibi daha üst ölçekli değişkenlerin bu tür etkileri gölgeleyebileceği de ifade edilmiştir.

Oliver, ${ }^{26}$ üç farklı şehir için karşılaştırmalı analiz yaptığı çalışmasında Hong Kong, Taipei ve Kaohsiung şehirlerindeki farklı durumlar irdelemiştir. Hong Kong kenti, büyük nüfus ve yolcu sayısıyla toplu taşıma odaklı bir ulaşım altyapısına sahipken, Kaohsiung ise tam tersi daha küçük bir nüfusla neredeyse tamamen özel otomobile endeksli bir şehir olarak değerlendirilmektedir. Diğer taraftan Taipei ise bu iki şehrin karması bir ulaşım altyapısına sahip olarak ele alınmıştır. Araştırma sonuçlarına göre erişilebilirlik etkilerinin ulaştırma ağının büyüklüğü ve popülerliği ile doğrudan ve güçlü bir ilişkisi değerlendirilmektedir. Bir başka deyişle, zaten çok güçlü ve güvenilir bir toplu taşıma altyapısına sahip bir şehir olan Hong Kong'ta konut fiyatları toplu taşıma hatlarına yakın olma konusunda duyarlı değilken, Taipei ve Kaohsiung gibi özel otomobil bağımlılığı olan şehirlerde konut fiyatlarını artırmaktadır. ${ }^{27}$ Bu sonuçlar göstermektedir ki her piyasada olduğu gibi, ulaştırma piyasasında da arzı sınırlı olan bir hizmet değer üretme konusunda daha büyük etkiler ortaya çıkarmaktadır.

Wanga \& Zhang tarafindan konut fiyatlarını etkileyen faktörlerle ilgili olarak yapılan bir başka çalışmada ise 2002-2008 yıllarında Çin'in önemli ve büyük şehirlerinde gerçekleşen 6294'ü ticari olmak üzere toplam 13.030 satş verisi analiz edilmiştir. Çalışmaya göre raylı sistem altyapısı nüfus, gelir düzeyi, arazi arzı, yapım maliyetleri gibi parametreler konut fiyatlarını belirleyen bileşenler arasındadır. Bu sonuçlara göre Çin'de raylı sistem altyapı hizmetlerinin konut fiyatlarını artırdığı gözlemlenmiştir. ${ }^{28}$

Literatüre Avrupa ülkelerinde yapılan çalışmaların da önemli katkıları olmuştur. Gadziński ve Radzimski ${ }^{29}$ tarafindan yapılan çalışmada, Polonya'nın ilk tramvay hatt ele alınmış, tramvay hattının yolcu davranışlarını nasıl değiştirdiği, konut yer seçimine olan etkisi ve konut fiyatlarına etkisiyle ilgili üç farklı konu incelenmiştir. Bu çerçevede raylı sistemin 1000 m koridorunda yer alan konutlarda 300 hane halkı anketi yapılmış ve 1400 konut saţş verisi temin edilmiştir. Araştırma kapsamında yapılan mülakat sonuçlarına göre güvenilir ve popüler bir raylı sistemin yolcu davranışlarını toplu taşıma ekseninde şekillendiren etkiler yaratmıştır. Diğer taraftan konut seçiminde özellikle kiralık konutlarda tramvay hattının büyük oranda dikkate alındığı görülmüştür. Raylı sistemin konut fiyatlarına etkisi konusunda farklı modellerle yapılan testlerde benzer sonuçlar üretilmiştir. Buna göre hatton şehir merkezinden geçtiği bölgelerde konut fiyatları etkilenmezken çeperlerde konut fiyatlarını etkilediği gözlemlenmiştir. ${ }^{30}$

\footnotetext{
${ }^{26}$ Oliver, 2013, s. 1-16.

${ }^{27}$ Oliver, 2013, s. 1-16.

${ }^{28}$ Wanga \& Zhang, 2014, s. 53-61.

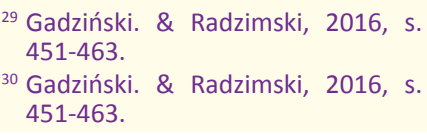


Raylı sistemlerle kentsel gayrimenkul piyasası arasındaki ilişki özellikle değer artışı tespiti ve toplu taşıma odaklı gelişme açısından hayati öneme sahiptir. Raylı sistemlerin ticari alan fiyatlarına etkisiyle ilgili literatür kaynak sayısı konuta göre nispeten sınırlıdır. Bu çerçevede Xu, Zhang ve Aditjandra, ${ }^{31}$ tarafindan yapılan çalışmada Çin'in Wuhan şehrindeki metro hatt istasyonlarının $400 \mathrm{~m}$ çapında yer alan ticari alan fiyat değişimleri incelenmiştir. 676 gözlem, hedonik modeli temel alan çoklu lineer regresyon ve mekansal ekonometrik regresyon ile test edilmiştir. Bulgular istasyonun 0-100 $\mathrm{m}$ yakınındaki ticari mekan fiyatlarının $\% 16,7,100-400 \mathrm{~m}$ yakınındaki konutların ise $\% 8$ düzeyinde artış gösterdiğini vurgulamaktadır. Bu değer artışlarının özellikle son dönemle kıt kaynaklar sebebiyle tartş̧ılan alternatif finansman çerçevesinde vergi artı̧̧ı gibi yöntemlerle kamuya geri döndürülmesinin amaçlandığı ifade edilmektedir. $^{32}$

Zhong \& Li'nin çalışmasına göre, konut fiyatlarının rayIı sistem yatırımlarına bağlı olarak değişimi istasyona olan mesafenin yanında raylı sistem tipine, bölgenin sosyo-ekonomik ve demografik durumuna, bölgenin arazi kullanım yapısına bağlı olarak ta değişmektedir. ABD'nin Los Angeles şehrinde yapılan araştırmada 2003-2004 yıllarında metro hatlarının etki alanındaki 958 müstakil (single-family), 10.078 çoklu aile konutları (muti-family) satış fiyatları 0-400 $\mathrm{m}, 400-800 \mathrm{~m}$ ve $800-1600 \mathrm{~m}$ aralıklarla ve hedonik bazlı faklı regresyon tipleriyle test edilmiştir. Bulgular, konum özelliklerini de içeren regresyon analizlerinin sonuçlarının daha güvenilir olduğunu göstermektedir. Bununla birlikte müstakil konut fiyatlarının raylı sistemden etkilenmediği, çoklu aile konutlarının ise artş̧ yönünde etkilendiği ifade edilmektedir. Diğer taraftan alternatif finansman konusunda yapılacak çalışmalarda değer artş̧ının belirlenmesinde kullanılacak yöntemin önemine işaret edilmiştir. ${ }^{33}$

Mulley, Tsai ve $\mathrm{Ma}^{34}$ çalışmalarını arazi rant teorisine odaklamıştr. Arazi değerleri ürün ve hizmetlere erişilebilirlikle ilişkilendirilmiştir. Buna göre ulaştırma altyapısındaki iyileşmeler ve erişebilirlikteki artşlar arazi fiyatını artırmaktadır. Sidney şehrinde yapılan çalışmada $7.2 \mathrm{~km}$ uzunluğa ve 14 istasyona sahip Sindey İç Bat Hafif Raylı Sistemi istasyonları etrafinda, 800 m'lik çemberlerden konut verileri toplanmıştı. Mulley vd. konut fiyatlarını, fiziksel özellikleri, çevresel özellikleri ve raylı sistem hatth ile mesafesini ölçerek yorumlamıştı. Bu çerçevede 2011 yılı verilerinde 1522 konut satışı dikkate alınmış ve bu veriler coğrafi ağırIıklı regresyon ile test edilmiştir. Bu yöntemdeki kabulde, her bir analiz noktasının yerel parametrik özellikleri vardır bu değerler diğer komşu noktalardan etkilenmektedir. Bu sebeple model çıktları diğer tek boyutlu modellere kıyasla gerçeğe yakın olmaktadır. Analiz sonuçlarına göre istasyon

\footnotetext{
${ }^{31}$ Xu, Zhang ve Aditjandra, 2016, s. 223-235. ${ }^{33}$ Zhong \& Li, 2016, s. 33-48.

${ }^{32} \mathrm{Xu}$, Zhang ve Aditjandra, 2016, s. 223-235. ${ }^{34}$ Mulley, Tsai ve Ma, 2018, s. 3-10.
}

etrafinda ilk 100 m'de yer alan konut fiyatları gürültü, kirlilik gibi sebeplerle olumsuz etkilenmektedir. Bununla birlikte istasyona her $100 \mathrm{~m}$ yaklaşııması konut fiyatlarını \% 0,5 oranında artirmaktadır.

Metro hatları, yapım maliyetleri yüksek olmakla birlikte özellikle metropol şehirlerde ulaşım faaliyetlerinin sürdürülebilirliği açısından büyük önem taşımaktadır. Bu çerçevede özellikle Çin, Hindistan gibi gelişmiş/gelişmekte olan ülkelerde raylı sistem yatırımları çok büyük hızla devam etmektedir. Sharma \& Newman ${ }^{35}$ tarafindan yapılan çalışmada, Hindistan'ın Bangalore şehrindeki metro hattının "etki alanı" ve "şehir geneli"ndeki konut fiyatlarına etkisi bir doktora tezi çerçevesinde incelenmiştir. Buna göre istasyon etrafinda 500 m'lik bir çemberde konut sathş verileri toplanmıştır. Süreç analizinde kullanılmak üzere 2012-2016 yılları arasında gerçekleşmiş 160.000 satış verisi, kesit analizinde kullanılmak üzere ise 2016 yılına ait 314.000 örnek elde edilmiştir. Hindistan'da konut satiş fiyatlarının arşivlenmesi güvenilir olmadığından veriler gayrimenkul değerleme firmalarından elde edilmiştir. Yöntem açısından hem süreç hem de kesit analizinde hedonik fiyat modeli kullanılımıştr. Bu çerçevede 2016 yılı verilerine dayanan kesit analizi sonuçlarına göre, metro istasyonları 500 m'ye kadar konut fiyatlarını \%35,8, 500m-1 km arasında \%19.3, 1-2 km arasında ise \%13.8 oranında artırmıştır. Bununla birlikte metro inşaatı ve işletmeye açılması arasında geçen sürede metro hatt genel erişilebilirliği artırdığı için şehir genelinde \%10,9'luk bir artı̧ yaratmıştır. Süreç analizinde kullanılan veri setleri farklı olduğundan sonuçlar da pararel olmakla birlikte farklı çıkmıştır. Buna göre, metro kaynaklı fiyat artış $500 \mathrm{~m}$ mesafeye kadar \%10.7, 1-2 $\mathrm{km}$ arasında $\% 8.7,500 \mathrm{~m}-1 \mathrm{~km}$ arasında ise $\% 25.3$ olarak gerçekleşmiştir. Bunun nedeni Bangalore 0-500 m arasında negatif dışsalllıklar sebebiyle en iyi erişimin $500 \mathrm{~m}-1 \mathrm{~km}$ arasında olması şeklinde açıklanmaktadır. Bununla birlikte süreç analizinde metro açılışında itibaren her yıl ilave \%1.8'lik artıştan bahsetmektedir.

Zhang \& Xu ${ }^{36}$ tarafindan Çin'in Wuhan şehrinde yer alan metronun gelişiminin konut, ofis ve ticari birimlerin fiyatlarını nasıl etkilediği yine hedonik fiyat yöntemi ile irdelenmiştir. Bu çerçevede 2013-2014 yılına ait 1604 konut ve 2015 yılına ait 678 ticari ve 844 ofis ünitesinin veri setleri elde edilmiştir. Sonuç olarak 300 m'lik çemberde yer alan etki alanında konut fiyatlarında \%6.5, ticari birimlerin fiyatlarında \%10.4 ve ofis fiyatlarına ise ortalama \%8.6 artış olmuştur. Burada ticari ünite fiyatlarının, metro istasyonuna mesafe açısından oldukça duyarlı olduğu değerlendirilmektedir.

\section{Sonuç}

Kent içi raylı sistemler ve özellikle metro hatları, trafik sıkışıklığından etkilenmeden erişime imkan sağlayan

\footnotetext{
${ }^{35}$ Sharma \& Newman, 2018, s. 70-86. $\quad{ }^{36}$ Zhang, M. \& Xu, 2017, s. 1-13.
} 
önemli ulaşım alternatifleridir. Bu sebeple özellikle metro istasyonu etrafinda şekillenen barınma ve iş hayat kurgusu, zaman kazancı açısından çok önemli bir avantajı barındırmaktadır. Zaman kazancının yanı sıra metro hatlarının; düzenli servis sıklıkları, güvenilir olması, kaza gibi olumsuz olasılıkların düşük olması, otobüs gibi kapasitesi düşük sistemlere göre daha konforlu olması gibi sebepler bu sistemleri cazip kılmaktadır.

Raylı sistemlerin arazi fiyatlarına etkisiyle ilgili konunun ilgi çekici olmasının temel nedenlerinden birisi; ortaya çıkan rantın değerlendirilmesi veya kamuya döndürülmesi düzleminde tartışılmasıdır. Diğer bir ifadeyle; raylı sistem yatırımından kaynaklanan arazi fiyat artş̧larının veya rantın belli oranda kamuya döndürülmesi, kamu için bir kaynak olarak araştırılmaya değer olmakta ve akademik yayınlarda da karşımıza çıkmaktadır. Bu çerçevede makaleye konu olan metro hatlarının konut fiyatlarına etkisi tartışması konut tipolojisinden arazi kullanışına, metronun evrimsel sürecinden istasyon tipolojisine kadar çeşitli düzlemlerde ele alınmıştır.

Araştırmaya konu olan çalışmalar (bkz Tablo 1), ağırlıkla $A B D$ ve Uzak Doğu'da yer bulan gelişmiş metro sistemleri olan ülkeleri konu almaktadır. Bunun en önemli sebebi gelişmiş ülkelerde 100 yıldan fazladır hizmet vermekte olan raylı sistem hatlarının ortaya çıkardığı etkilerin merak konusu olmasıdır. İinci bir nedeni ise; alternatif finansman yöntemi olarak kamuya katkısının araştırılmasıdır. Verilerin 4 ana kanaldan temin edildiği görülür: (1) resmi kurumlar, (2) gayrimenkul piyasasını takip eden kuruluşlar, (3) gayrimenkul değerleme firmaları, (4) internet taraması.

Literatür taramasının sonuçlarından birisi, 40 çalışmanın 36 'ında konut fiyatını etkileyen parametrelerin çoğunlukla hedonik fiyat modeline dayanan farklı regresyon modelleri ile test edildiği bulgusudur. Bununla birlikte öncesi-sonrası analize dayanan istatistiksel test yöntemlerine de rastlamak mümkündür. Sonuç olarak çalışmaların tamamı nicel bir ölçme tekniği kullanılarak değerlendirilmiştir.

Kent içi raylı sistem arzının konut fiyatlarını artıracağı yönündeki teorik savlar yoğun olmakla birlikte, kent içi raylı sistemlerin farklı durum ve mekanlara göre değişik tepkiler doğurduğu gözlenmiştir. Ancak yine de raylı sistem hattının geçtiği bölgenin sosyo-ekonomik ve demografik özellikleri ile genel ulaşım ağı ekseninde şekillenen etkileri, her bir hatta, konut fiyatları açısından farklı etkiler yaratmaktadır. Bu çerçevede makalede işlenen konuya bakış açıları da ülkelere veya amaçlara bağıı olarak farkılış̧maktadır. Özellikle Kamu Özel İşbirliği (PPP -Public Private Partnership) projelerinde farklı senaryolar üzerinden hem raylı sistem ağının gelişmesine hem de finansman teminine/desteğine yönelik uygulamalar bulunmaktadır. Örneğin Uzak Doğu ülkelerinde özellikle Hong Kong'da toplu taşıma odaklı gelişme (TOD-transit oriented development) çerçevesinde raylı sis- tem istasyonunu merkeze alan bir kentsel büyüme ve gelişme modeli uygulanmaktadır. Burada amaç kentsel gelişme alanlarında gayrimenkul geliştirme projeleri üzerinden elde edilecek rantın, raylı sistem finansmanında da kullanılması şeklinde özetlenebilir. Hong Kong'da raylı sistemlerin tüm süreçlerinden sorumlu MTR (Mass Transit Railway Corporation) firması raylı sistem ve kent planlaması konularını birlikte koordine ederek proje, imalat, işletme finansman gibi konularda bütüncül bir yaklaşımla şehrin toplu taşıma odaklı evrimine öncülük ettiği tespit edilmiştir.

Bir başka yaklaşımda ise çoğunlukla ABD eyaletlerindeki bazı uygulamalarda genel olarak raylı sistemlerden ortaya çıkan rantın arsa vergisini artırmak yönünde kamuya döndürüldüğü bilinmektedir. Diğer taraftan gelişmiş Avrupa ülkelerinde raylı sistem altyapısı üzerinden değer yaratma çerçevesinde kamu özel işbirliği projeleriyle alternatif finansman temini konusunda örneklere rastlanmıştır.

Bununla birlikte her piyasada olduğu gibi, ulaşttrma piyasasında da arzı sınırlı olan bir hizmet değer üretme konusunda daha büyük etkiler ortaya çıkarmaktadır. Bir başka deyişle, metro hattının konut fiyatlarına etkisi, büyük oranda o mekanın metroya duyduğu ihtiyaç nispetince şekillenmektedir.

Sonuç olarak, metro hatlarının konut fiyatlarına etkisi konusunda ağırlıkla hedonik fiyat yöntemiyle test edilen hipotezler büyük oranda doğrulanmaktadır. Konunun akademik boyutta tartışılmasının yanı sıra buradan elde edilen rantın bir şekilde kamuya döndürülmesi konusunda makalede de bahsedildiği gibi farklı uygulama ve yöntemler kullanılmaktadır. Dünya genelinde yaşanan ekonomik darboğazlar sebebiyle ileriye dönük olarak bu tür çalışmaların artarak devam edeceği bulgusuna ulaşılmıştr.

\section{Kaynaklar}

Alonso, W., 1964. Location and Land Use.

Banister, D. \& Goodwin, M. T., 2011. Quantification of the nontransport benefits resulting from rail investment. Journal of Transport Geography, Issue 19, pp. 212-223.

Beyazit, E., 2015. Are wider economic impacts of transport infrastructures always beneficial? Impacts of the Istanbul Metro on the generation of spatio-economic inequalities. Journal of Transport Geography, Issue 45, pp. 12-23.

Cao, X. J. \& Nelson, D. P., 2016. Real estate development in an ticipation of the Green Line light rail transit in St.Paul. TransportPolicy, Issue 51, pp. 24-32.

Dai, X., Bai, X. \& Xu, M., 2016. The influence of Beijing rail transfer stations on surrounding housing prices. Habitat International, Issue 55, pp. 79-88.

Du, H. \& Mulley, C., 2007. The short-term land value impacts of urban rail transit: Quantitative evidence from Sunderland, UK. Land Use Policy, Issue 24, pp. 223-233.

Efthymiou, D. \& Antoniou, C., 2013. How do transport infrastructure and policies affect house prices and rents? Evidence from Athens, Greece. Transportation Research, pp. 1-22. 
Eryılmaz, Y., 2013. Ulaşım Altyapılarının Arazi Değer Artışına Etkileri -Tem Otoyolu İstanbul Anadolu Kesimi Örneği. İstanbul: İstanbul Teknik Üniversitesi, Fen Bilimleri Enstitüsü.

Gadziński, J. \& Radzimski, A., 2016. The first rapid tramline in Poland: How has it affected travel behaviours, housing choices and satisfaction, and apartment prices?. Journal of Transport Geography, Issue 54, pp. 451-463.

Ge, X. J., Macdonald, H., Ghosh, S., 2012. Assessing The Impact Of Rail Investment On Housing Prices In North-West Sydney. Adelaide, Australia, s.n.

İnanoğlu, G. E., 2014. Kadıköy - Kartal Raylı Taşıma Sistemi Ve Konut Fiyatları Değişiminin İncelenmesi. İstanbul: Yıldız Teknik Üniversitesi, Fen Bilimleri Enstitüsü.

Mulley, C. \& Hong Tsai, C., 2016. When and how much does new transport infrastructure add to property values? Evidence from the bus rapid transit system in Sydney,Australia. TransportPolicy, Issue 51, pp. 15-23.

Mulley, C., Tsai, C.-H. \& Ma, L., 2018. Does residential property price benefit from light rail in Sydney?. Research in Transportation Economics, Cilt 67, pp. 3-10.

Oliver Shyr, D. E. A. J. W. T. H. a. O. L., 2013. Where Do Home Buyers Pay Most for Relative Transit Accessibility? Hong Kong,Taipei and Kaohsiung Compared. Urbans Studies, pp. 1-16.

Papon, F., Nguyen-Luong, D. \& Boucq, E., 2015. Should any new light rail line provide real estate gains, or not? The case of the
T3 line in Paris. Research in Transportation Economics, Issue 49, pp. 43-54.

Rosen, S., 1974. Hedonic Prices and Implicit Markets:Product Differentiation in pure Competition. The Journal of Political Economy, Cilt 82, pp. 34-55.

Sharma, R. \& Newman, P., 2018. Does urban rail increase land value in emerging cities? Value uplift from Bangalore Metro. Transportation Research Part A, Cilt 117, p. 70*86.

Wanga, Z. \& Zhang, Q., 2014. Fundamental factors in the housing markets of China. Journal of Housing Economics, Issue 25, pp. 53-61.

Wardrip, K., 2011. Public Transit's Impact on Housing Costs: A Review of the Literature. Washington/USA, Center for Housing Policy and National Housing Conference, pp. 1-12.

$\mathrm{Xu}$, T., Zhang, M. \& Aditjandra, P. T., 2016. The impact of urban rail transit on commercial property value:New evidence from Wuhan, China. Transportation Research Part A, Issue 91, pp. 223-235.

Yankaya, U. \& Çelik, H., 2005. İzmir metrosunun konut fiyatları üzerindeki etkilerinin hedonik fiyat yöntemi ile modellenmesi. İzmir, D.E.Ü.ii.B.F. Dergisi, pp. 61-79.

Zhang, M. \& Xu, T., 2017. Uncovering the Potential for Value Capture from Rail Transit Services. Journal of Urban Planning and Development, Cilt 143, pp. 1-13.

Zhong, H. \& Li, W., 2016. Rail transit investment and property values: An old tale retold. TransportPolicy, pp. 33-48. 